\title{
Effect of processing, storage and type of glass packaging on the quality of jelly produced from a Brazilian Cerrado fruit
}

\author{
Mariana Crivelari da CUNHA ${ }^{1}$, Jéssyca Santos SILVA ${ }^{1}$, Jéssica Sousa GUIMARÃES ${ }^{1}$, \\ Elisângela Elena Nunes CARVALHO ${ }^{1}$, Eduardo Valério de Barros Vilas BOAS ${ }^{1 \star ~(D) ~}$
}

\begin{abstract}
The objective of this study was to prepare a jelly with the pulp of curriola as raw material and evaluate the effect of processing, type of glass packaging (transparent and amber) and storage time on the quality of the jelly by means of physical (color), chemical (proximal composition, total soluble solids, titratable acidity and $\mathrm{pH}$ ), microbiological (coliforms at $35^{\circ} \mathrm{C}$ and $45^{\circ} \mathrm{C}$, filamentous fungi and Salmonella sp.) and sensorial analyses (sensory acceptance and purchase intent). For this, the raw material and the freshly prepared jelly were compared and a completely randomized design in factorial $2 x 5$ was used. There were two levels of light exposure (transparent packaging and amber packaging) and five storage times (0, 3, 6, 9 and 12 months), with four replicates. Processing affected all physical, chemical and microbiological characteristics of the freshly prepared jelly. Between the two factors studied, only the storage time significantly influenced the jelly quality, except protein, ash, dietary fiber content and taste and purchase intention. According to the microbiological analysis, the product is within the legislated recommendations. It was well accepted sensorially and can be kept under ambient conditions and still maintain its durability for up to twelve months.
\end{abstract}

Keywords: Pouteria ramiflora (Mart) Radlk; shelf life; nutrition value; quality; processing.

Practical Application: Adding value and exploring the nutritional and sensory potential of exotic fruits.

\section{Introduction}

The Brazilian Cerrado has a high number of fruit species with great economic and nutritional potential, whose fruits can be consumed in either the fresh or processed form, such as in juice, jams, jellies and liqueurs (Damiani et al., 2012a, b; Silva et al., 2013). Among these fruit species there is Pouteria ramiflora (Mart.) Radlk., belonging to the Sapotaceae family, commonly found in the Cerrado biome. Its fruit is popularly known as "curriola" or "guapeva pilosa" or "grão-de-galo" (Perfeito et al., 2005; Rodrigues et al., 2017).

The curriola tree measures about 10 meters in height and its fruiting period occurs between January and March, mainly in the regions, which include the Cerrado. The fruits are of the berry type, of piriform format and even when ripe, present a greenish-colored peel and white-colored pulp, with a single seed (Silva et al., 2001; Silva, 2009). According to Morzelle et al. (2015), the rind and the seed of curriola correspond to $56.68 \%$ of the total weight of the fruit, with an average weight of $28.61 \mathrm{~g}$,

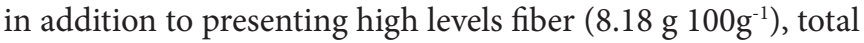

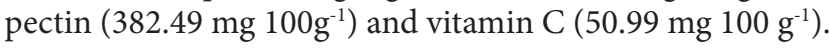

Some studies have shown that plants of this genus have been used both in food, as well as in folk medicine, some biological activity being reported such as antioxidant action (Morzelle et al., 2015; Silva et al., 2009), anti-inflammatory and antinociceptive (Fontes et al., 2009), antimicrobial and antifungal agents (Alves et al., 2000). Therefore, these native and regional fruits are vehicles made up of compounds with nutritional, functional and sensorial properties, which may stimulate their use in the formulation of new products, aiming at their enhanced use and promoting sustainable development in the Brazilian Cerrado region (Queiroz, 2011; Silva et al., 2017; Souza et al., 2012).

Considering, therefore, the seasonal production of this and other fruit species, the techniques applied to the preservation of foods are necessary to guarantee the consumption of food products for long periods of time. As a result the processing of jellies contributes to the preservation of the fruits, extending the shelf life and reducing chemical and microbiological changes that naturally affect the raw material used (Leong \& Oey, 2012; Silva et al., 2006). It is therefore necessary to obtain more information about the stability of the components naturally present in Cerrado fruits, in order to evaluate the quality and useful life, as well as to promote the development of new products with a high added value. According to Cunha et al. (2019), the effect of processing and storage on the quality of murici jelly [Byrsonima crassifolia (L.) Rich] affects the nutritional, microbiological content and promotes better sensory acceptance.

Therefore, in view of the need to increase availability and add value to Brazilian native fruits, recent studies have also shown that fruit processing in the form of jellies is perfectly viable, through the combination of different exotic fruits, such as mixed jelly elaborated with different proportions of cambuci [Campomanesia phaea (Berg) Landr], jabuticaba (Myrciaria spp.) and pitanga (Eugenia uniflora L.) (Curi et al., 2019a), as well 
as the viability in the influence of microwave processing on functional compounds and sensory acceptance of blackberry jelly (Curi et al., 2019b) and the harmonization with other types of food, such as brie cheese with jellies of different species of native physalis (Physalis L.) (Curi et al., 2018).

Demand for processed products with sensory characteristics similar to fresh foods is increasing. Thus, meeting that demand depends on proper forms of packaging. To prevent losses in physical, chemical, nutritional and sensory characteristics, packages that block the incidence of light are used (Miranda et al., 2012). According to Azeredo et al. (2012), the use of light barrier packaging is an effective way of minimizing photodegradation reaction and thus avoiding the degradation of food constituents. Thus, it is assumed that appropriate packaging can maintain the physical, chemical, nutritional and sensory characteristics of the product throughout the storage time.

The purpose of this work was the elaboration of a jelly using the raw material of the curriola pulp and the evaluation of the processing effect and the type of glass packaging (with and without exposure to light) and the storage duration, on the quality of the curriola jelly, through physical, chemical, microbiological and sensorial analyses.

\section{Materials and methods}

\subsection{Obtaining the raw material}

Curriola pulp acquired from the Pureza Frutas do Brasil company located in Aragarças - Goiás, was transported to the Fruits and Vegetables Postharvest Laboratory of the Federal University of Lavras, Lavras - Minas Gerais, packed in polyethylene bags with a capacity of $1 \mathrm{~kg}$, and stored at $-18^{\circ} \mathrm{C}$.

\subsection{Jelly preparation}

The conventional jelly formulations were elaborated considering the proportion for the manufacture of extra type jellies, which are elaborated in a 1:1 pulp/commercial sugar proportion using a $1 \%$ pectin concentration (Brasil, 1978). For the preparation of the jelly, $5 \mathrm{~kg}$ of pulp, $1 \%$ of commercial pectin and $5 \mathrm{~kg}$ of crystal sugar and $1 \%$ citric acid were used in a single batch, on the same day. After processing, the curriola jelly conditioned in different types of glass packaging (transparent and amber) was stored ambient conditions for twelve months.

\subsection{Analysis}

\section{Physical analyses}

Color was determined using the Konica Minolta CR-400 colorimeter (Minolta, São Paulo, Brazil) calibrated according to CIE system with $L^{*}, a^{*}$ and $b^{*}$ (illuminant D65) measurement. The parameter $L^{\star}$ represents the clarity, with values between 0 (totally black) and 100 (totally white), while the hue angle (ohue) corresponds to the tonality or identifies the color at a $360^{\circ}$ angle and Chroma $\left(\mathrm{C}^{\star}\right)$ corresponds to color saturation or intensity.

\section{Chemical analyses}

The water activity of the samples was measured instrumentally using the Aqualab (Aqualab Series 3TE) direct apparatus at $25^{\circ} \mathrm{C}$. The hydrogen potential was determined using $\mathrm{pHmeter}$ (Schott Handylab), at $25^{\circ} \mathrm{C}$. The determination of the titratable acidity was performed by titration with $0.01 \mathrm{~mol} \mathrm{~L}^{-1} \mathrm{NaOH}$ solution using $1 \%$ phenolphthalein as indicator and the results are expressed as g citric acid $100 \mathrm{~g}^{-1}$. Total soluble solids were determined by digital refractometry (Atago PAL) with automatic temperature compensation at $25^{\circ} \mathrm{C}$ and the results were expressed as percentage of soluble solids.

The analysis of moisture, lipids, protein (nitrogen conversion factor of 6.25), fixed mineral residue (ash) and total dietary fiber were performed according to Official Methods of Analysis (Association of Official Analytical Chemists, 2012). The nitrogen-free extract (NFE) was obtained by subtracting the values obtained from previous analyzes of $100 \mathrm{~g}$ of sample, in the whole matter. The results were expressed as percentage of fresh matter $\left(\mathrm{g} 100 \mathrm{~g}^{-1}\right)$. The total energy value was estimated using the Atwater conversion values, described by Zou et al.

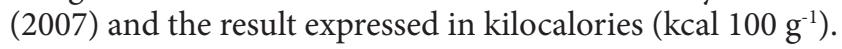

\section{Microbiological analyses}

The microbiological analyses carried out on the obtained pulps and jellies were coliforms at $35^{\circ} \mathrm{C}$ and $45^{\circ} \mathrm{C}$, filamentous fungi, yeasts and Salmonella sp. The most probable number (MPN) technique was used for the determination of coliforms and for the analyses of filamentous fungi, yeasts and Salmonella $\mathrm{sp}$, we used the standard count in Petri dishes, according to the methodologies described by the American Public Health Association (2001).

\section{Sensory analyses}

The sensorial analysis was carried out with the approval of the Research Ethics Committee of the Federal University of Lavras under process No. 502.167, made at each storage time, with the participation of 500 untrained panelists, of both sexes, with ages varying from 15 to 60 . The jelly samples were served in balanced order and monodically on Fhorm brand toasts, used as vehicles, coded with three digit random numbers. The panelists evaluated the product acceptance by means of a nine point hedonic scale (" 1 " dislike extremely and "9" like extremely). The purchase intention test was performed using the hedonic scale of five points ("1" would certainly not buy and " 5 " would certainly buy), according to Stone et al. (2012).

\section{Statistical analysis}

Statistical analysis was performed using the Sisvar software (Ferreira, 2011). For processing, the data are presented as mean \pm standard deviation. The Student's t-test significance $(\mathrm{p}<0.05)$ was used to evaluate for differences between the curriola pulp and freshly prepared jelly. The storage time, the polynomial regression models and the determination coefficients $\left(R^{2}\right)$ were selected based on the significance of the $F$ test of each model, and the significance of $1 \%$ probability was only performed for the centesimal analysis and for the other analyzes, the significance was $5 \%$ probability. 


\subsection{Experimental design}

The impact of processing was evaluated on freshly prepared jelly and curriola pulp. A completely randomized design (CRD), in factorial $2 \times 5$, was used with 2 levels of light exposure (transparent glass packaging, light exposure and amber glass packaging - no exposure to light) and five storage times ( 0 , 3, 6, 9 and 12 months), with four replicates. The experimental portion consisted of $100 \mathrm{~g}$ of jelly (two glass jars of $50 \mathrm{~mL}$ each).

\section{Results and discussion}

\subsection{Processing Effect}

The results obtained from the physical and chemical characterization of both the raw material used in the preparation of the jelly and the final product are presented in Table 1.

The processing, in general, significantly affected $(\mathrm{p}<0.05)$ the analyzed variables, with a decrease of the proximal composition (moisture, fat, protein and ash), chemical analyses values ( $\mathrm{pH}$ and water activity) and physical analyses values ( $\mathrm{L}^{\star}, \mathrm{C}^{*}$ and ohue). There was an increase in the soluble solids content, the titratable acidity, the nitrogen-free extract content and, consequently, the energy value of the freshly prepared product.

While natural sugars are the main glycidic representatives of the curriola pulp, the sugar added during preparation is the main glycidic of the curriola jelly. Thus, the higher nitrogen-free content of jelly is a reflection of the addition of sugar, as the higher acidity and lower $\mathrm{pH}$ is a reflection of the addition of citric acid, as well as the concentration of these compounds by heat. Since sugars and organic acids are water soluble, the increase in nitrogen-free fraction and titratable acidity culminates in the increase of soluble solids. On the other hand, the addition of sugar and citric acid, mainly sugar, due to the higher concentration, proportionally reduces the other proximal compounds, as

Table 1. Mean values of the physical and chemical characteristics of curriola pulp and curriola jelly, at initial time with their respective standard deviations.

\begin{tabular}{|c|c|c|}
\hline Physicochemical characteristics & Pulp of curriola ${ }^{1}$ & Curriola jelly $^{2}$ \\
\hline 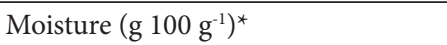 & $83.91 \pm 0.24^{\mathrm{a}}$ & $31.10 \pm 1.52^{\mathrm{b}}$ \\
\hline Fat $\left(\mathrm{g} 100 \mathrm{~g}^{-1}\right)^{*}$ & $0.61 \pm 0.02^{\mathrm{a}}$ & $0.10 \pm 0.01^{\mathrm{b}}$ \\
\hline Protein $\left(\mathrm{g} 100 \mathrm{~g}^{-1}\right)^{*}$ & $1.07 \pm 0.02^{\mathrm{a}}$ & $0.83 \pm 0.07^{\mathrm{b}}$ \\
\hline Ash $\left(\mathrm{g} 100 \mathrm{~g}^{-1}\right)^{\star}$ & $0.37 \pm 0.03^{\mathrm{a}}$ & $0.31 \pm 0.02^{\mathrm{b}}$ \\
\hline 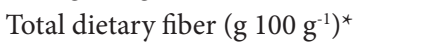 & $11.43 \pm 0.12^{\mathrm{b}}$ & $14.92 \pm 0.95^{\mathrm{a}}$ \\
\hline Nitrogen-free extract $\left(\mathrm{g} 100 \mathrm{~g}^{-1}\right)^{\star}$ & $2.59 \pm 0.08^{\mathrm{b}}$ & $52.72 \pm 3.72^{\mathrm{a}}$ \\
\hline Total energy value $\left(\mathrm{kcal} 100 \mathrm{~g}^{-1}\right)^{*}$ & $20.19 \pm 0.04^{\mathrm{b}}$ & $215.18 \pm 1.26^{\mathrm{a}}$ \\
\hline Pectin (mg de galacturonic acid $100 \mathrm{~g}^{-1}$ ) & $448.98 \pm 28.19$ & - \\
\hline Soluble solids (\%) & $8.63 \pm 0.28^{\mathrm{b}}$ & $67.75 \pm 7.37^{\mathrm{a}}$ \\
\hline Titratable acidity (g citric acid $100 \mathrm{~g}^{-1}$ ) & $0.26 \pm 0.00^{\mathrm{b}}$ & $2.60 \pm 0.16^{\mathrm{a}}$ \\
\hline $\mathrm{pH}$ & $4.74 \pm 0.01^{\mathrm{a}}$ & $3.57 \pm 0.04^{\mathrm{b}}$ \\
\hline Water activity & $0.95 \pm 0.01^{\mathrm{a}}$ & $0.90 \pm 0.00^{\mathrm{b}}$ \\
\hline Value $L^{*}$ & $37.64 \pm 0.64^{\mathrm{a}}$ & $22.40 \pm 0.57^{\mathrm{b}}$ \\
\hline Chroma $\left(C^{*}\right)$ & $26.08 \pm 0.74^{\mathrm{a}}$ & $12.64 \pm 0.98^{\mathrm{b}}$ \\
\hline ohue & $83.43 \pm 0.08^{\mathrm{a}}$ & $72.97 \pm 0.87^{\mathrm{b}}$ \\
\hline
\end{tabular}

observed (Table 1). Although various factors, such as heat from cooking, light, oxygen and $\mathrm{pH}$ interfere with the physical and chemical properties of the product due to cell disintegration, nutrient degradation and enzymatic inactivation (Leong \& Oey, 2012; Machado et al., 2013; Maia et al., 2007).

The proximal compounds tend to be quite stable from a quantitative point of view and the observed changes are mainly due to the addition of sugar. The fresh jelly presented less water activity than the pulp used as raw material, as expected, since the sugar used in the formulation is widely used for this purpose, either rustically or in the food industry.

Regarding the effect of processing on the color analysis, it was found there was a reduction in the means of the variables $L^{\star}, C^{*}$ and ${ }^{\circ}$ hue, comparing the pulp and freshly prepared jelly data (Table 1 ). The $\mathrm{L}^{\star}$ value of the freshly prepared jelly was lower than that of the raw material, suggesting the darkening of the final product, due to processing. The darkening can be explained by factors that gave rise to non-enzymatic reactions, such as the Maillard reaction and caramelization (Damiani et al., 2009), as well as the oxidation of pigments present (chlorophyll), generating a darker color tone. Chroma $\left(\mathrm{C}^{\star}\right)$ and hue angle $\left({ }^{\circ}\right.$ hue $)$ decreased after processing by $51.52 \%$ and $12.53 \%$, respectively. The possible explanation for this fact may be due to pigment degradation and/or oxidation. Therefore, the higher the chromaticity values, the brighter the coloration and consequently the more attractive the food. The ohue indicates the perceptible color of the product (Oliveira et al., 2014). Thus, with the reduction of chromaticity and ohue values, the effect of the processing indicates changes in coloration towards yellowish green.

\subsection{Effect of storage time and different types of glass packaging}

Regarding the results of stored curriola jelly, only the storage time significantly influenced $(\mathrm{p}<0.05)$ the physical, chemical and sensorial variables analyzed and no significant effect was observed for the glass packaging factor.

Regarding the variables water activity, $\mathrm{pH}$, titratable acidity, soluble solids and color, polynomial regression models, at $5 \%$ significance level, were established from the experimental results of the studied variables. Their suitability for the mathematical models can be verified by the high coefficients of determinations $\left(\mathrm{R}^{2}\right)$ which explain between $90.73 \%$ to $97.58 \%$, according to Figure 1 .

A quadratic polynomial model was adjusted for water activity of curriola jelly throughout storage, ranging from 0.9 at initial time (freshly prepared jelly) to 0.87 at 12 months of storage (Figure 1). The small decrease observed in water activity may be associated with a possible inversion of sucrose, a process dependent on the water available in the system. According to Broomes \& Badrie (2010), water activity determines the lower limit of water available for microbial growth. The water observed in the jellies throughout storage was high enough to support the proliferation of microorganism, since generally the minimum water activity for their development, including most filamentous fungi and yeast is 0.80 (Franco \& Landgraf, 2008; Jay, 2005).

A slight downward trend in $\mathrm{pH}$ was observed from the beginning to the end of the storage ( 3.57 to 3.38 ), and a cubic 

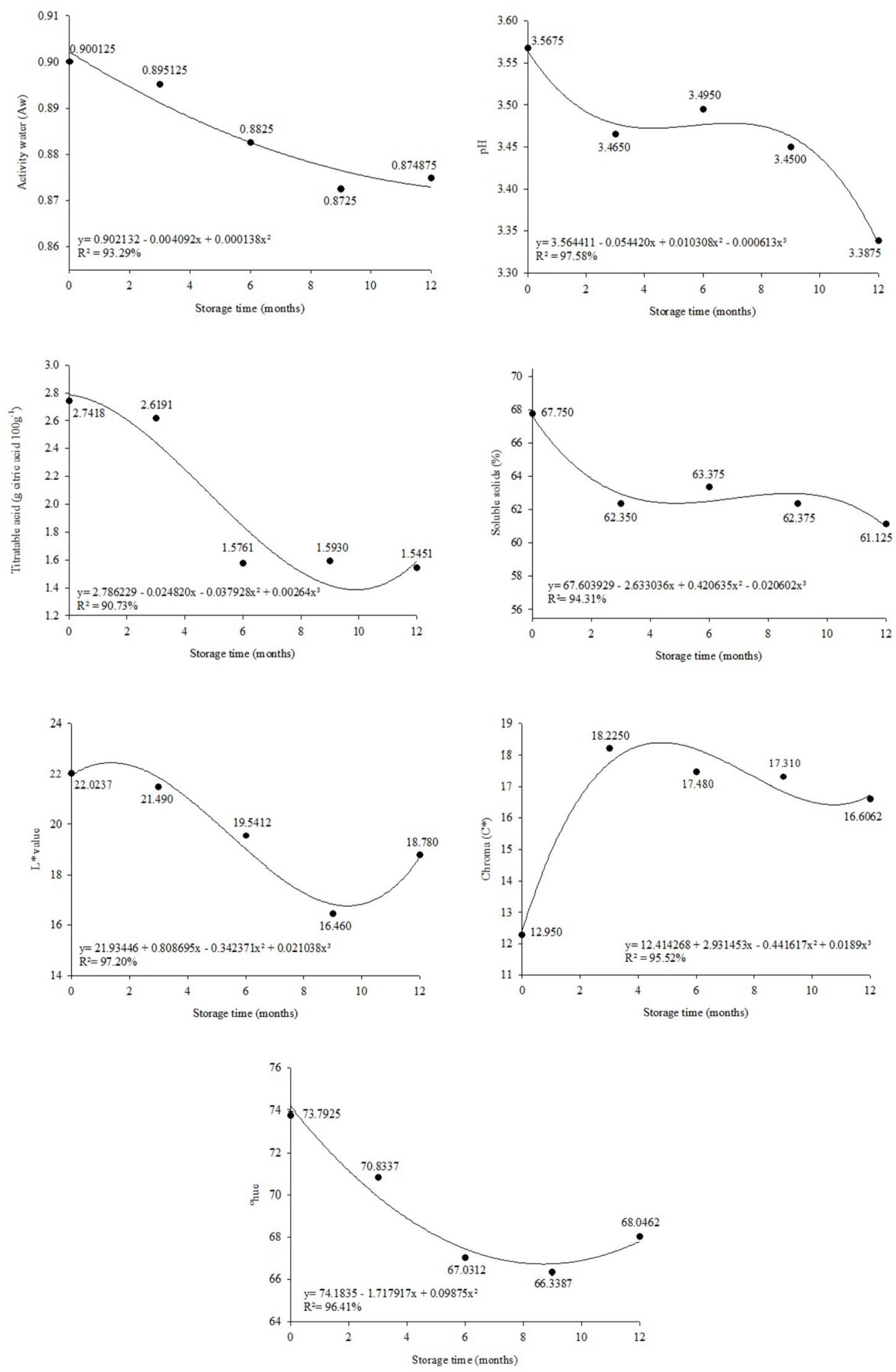

Figure 1. Adjustment models $(\mathrm{p}<0.05)$ performed in physical $\left(\mathrm{L}^{*}, \mathrm{C}^{*}\right.$ and ${ }^{\circ}$ hue $)$ and chemical analysis $(\mathrm{Aw}$, $\mathrm{pH}$, titratable acidity and solid soluble $)$ of curriola jelly packaged in glass containers (with and without exposure to light) stored under environmental conditions $\left(20.8^{\circ} \mathrm{C} \pm 2.87\right.$ and $69.6 \%$ $\mathrm{RH} \pm 10.51)$ for one year in storage. 
polynomial model was adjusted for this behavior. A similar model was observed for titratable acidity, although the drop was more striking, ranging from $2.75 \%$ to $1.5 \%$. The reduction in titratable acidity may be associated with the possible degradation of organic acids and the possible polymerization of free galacturonic acids to the pectic mesh, which causes a reduction in the acidity of the product during storage. The behavior and values found for curriola jelly were similar to those found by Damiani et al. (2012a), in mixed jelly of araça and marolo, during the twelve months of storage and by Santos et al. (2012) in cagaita jelly, during 120 days of storage.

The soluble solids content presented a declining behavior over the storage time, with a reduction equivalent to $9.78 \%$, adjusting to a cubic polynomial model. The most intense reduction period was observed in the first three months of storage, followed by six months of stabilization. This behavior differs from that found by Freitas et al. (2008), analyzing the influence of the storage time of 150 days on the soluble solids content of gabiroba jelly, resulting in an increase of $65.08 \%$ to $70.08 \%$. According to National Food Standards Commission Resolution No. 12/1978 (Brasil, 1978), the minimum soluble solid content in jellies must be $62 \%(w / w)$. Based on the polynomial model, the curriola jelly presented the minimum soluble solids content recommended by law during eleven months of storage.

Concerning the color, a cubic behavior of the $\mathrm{L}^{*}$ value was observed, marked by reduction in the first 9 months of storage, followed by elevation. This is associated to non-enzymatic browning reactions, such as the Maillard reaction, since in products with high concentrations of sugar and low $\mathrm{pH}$ values $(\mathrm{pH}<5)$, there may be formation of intermediates such as hydroxymethylfurfural (HMF) (Damiani et al., 2012a, b),during prolonged storage. However, according to studies by Dias et al. (2011), the darkening of the banana peel jelly during the storage period may also come from oxidation reactions of the pigments present in the product.

The chromaticity $\left(\mathrm{C}^{\star}\right)$ fit he model cubic polynomial, and it was possible to observe an increase in its values in the first months of storage, followed by a stabilization trend. According to Kirca et al. (2007) the higher the chroma values the brighter and consequently the more attractive the food will be.

As for ohue, a quadratic mathematical adjustment with a declining tendency was possible during the initial months of storage, followed by a slight increase. The yellowish green jelly had increased the intensity of yellow with storage, possibly due to degradative processes of chlorophyll, a pigment present in the curriola pulp. According to Streit et al. (2005), chlorophylls are chemically unstable pigments and can be changed easily, generally modifying the perception and quality of the product. In the case of the present study, pigment degradation may have been a result of factors such as changes in acidity of the product during the storage period.

The proximal components and energy were also influenced by storage time $(\mathrm{p}<0.01)$, except protein, ash and dietary fiber. Cubic adjustment for moisture, fat, nitrogen free extract and energy were obtained, with the determination coefficient $\left(\mathrm{R}^{2}\right)$ of the polynomial models ranging from $87.67 \%$ to $96.95 \%$ (Figure 2 ).
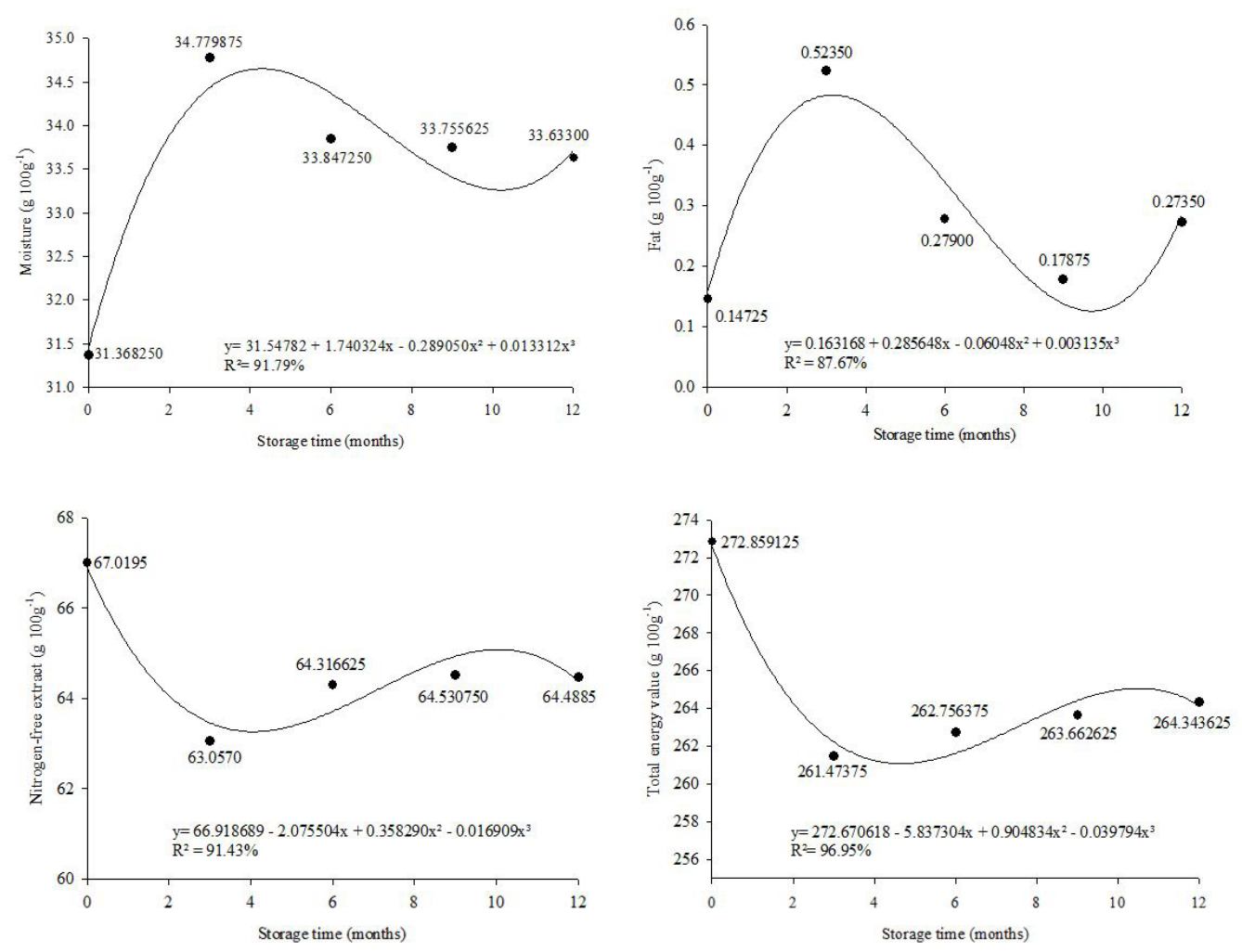

Figure 2. Behavior during storage time $(\mathrm{p}<0.01)$ of proximal composition (moisture, fat, nitrogen-free extract and total energy value) of curriola jelly, packaged in glass containers (with and without exposure to light) and stored under ambient conditions $\left(20.8^{\circ} \mathrm{C} \pm 2.87\right.$ and $69.6 \%$ $\mathrm{RH} \pm 10.51$ ) for one year in storage. 
It can be observed that the moisture content increased until the $4^{\text {th }}$ month, followed by fall and stabilization until the end of storage. According to the Collegiate Board Resolution No 12/1978 (Brasil, 1978), the minimum moisture content for 'extra' type jellies corresponds to $35 \%$ (w/w). Thus, despite the variation in moisture contents, during the course of the storage time the curriola jelly does not meet the standards recommended by the legislation. This behavior is similar to that found by Mota (2006), during the storage of blackberry jelly of different cultivars for 90 days. This is differently from the results found by Damiani et al. (2012a) who found a decline in moisture content during the storage time (12 months) of mixed jelly of araçá and marolo.

There was an oscillatory behavior, followed by an increase and subsequent reduction in the fat content, during the jelly storage period, although the oscillation was small

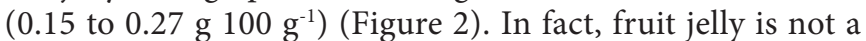
lipid source, being a poor vehicle of this nutrient. According to Andrade (2006) and Araujo (2011), this oscillation can be attributed to oxidative processes (presence of oxygen, light, acidity and heat), as well as the environmental conditioning during the prolonged storage time.

The average protein, ash and dietary fiber contents, variables not

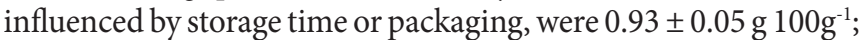

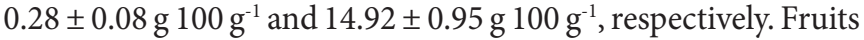
and their products, such as jellies, are usually low in protein, as noted in this paper. The behavior ( $p>0.05)$ of ash was similar to that found by Damiani et al. (2012a), in the development and evaluation of the useful life of araça and marolo mixed jelly and by Pavlova et al. (2013), in the study of quality and lifetime of mixed raspberry and peach jelly.

Regarding the behavior of nitrogen-free extract content and energy value, a similar adjustment of cubic order was observed for both variables (Figure 2), similar to that observer for soluble solids (Figure 1). In fact, the main soluble solids in a jelly are sugars, determined in the nitrogen-free extract content, the major promoter of the energy value of this food product. Reduction in the first three months, followed by a stabilization trend toward the end of storage was observed, which represents a total decline of $3.78 \%$ for the nitrogen-free extract and $3.12 \%$ for the energy value. Therefore, the reduction during storage time, according to Pavlova et al. (2013), is due to contribution of the reducing sugars to the non-enzymatic browning reactions (Maillard reaction) and the formation of complex intermediates (hydroxymethylfurfural) until the end of twelve months.

\subsection{Microbiological analyses and sensory acceptance of jelly}

Regarding the microbiological analyses, the presence of coliforms at $35{ }^{\circ} \mathrm{C}$ or $45^{\circ} \mathrm{C}$, filamentous fungi, yeasts and Salmonella sp were not detected in the curriola jelly throughout the storage time, which proves the safety of the product.
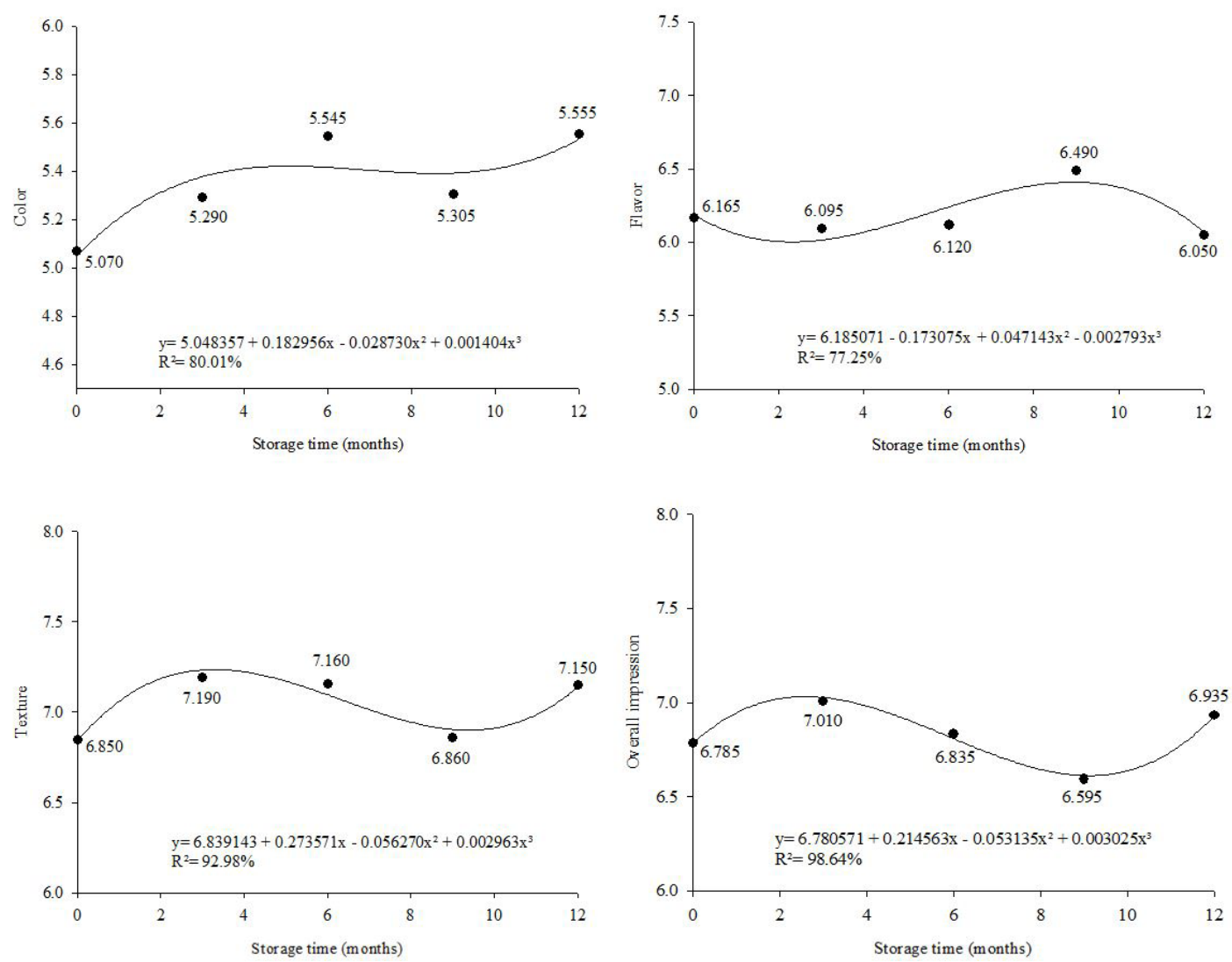

Figure 3. Behavior during storage time $(\mathrm{p}<0.05)$ of sensory parameters (color, aroma, texture and overall impression) of curriola jelly, packaged in glass containers (with and without exposure to light) and stored under ambient conditions $\left(20.8^{\circ} \mathrm{C} \pm 2.87\right.$ and $\left.69.6 \% \mathrm{RH} \pm 10.51\right)$ for one year in storage. 
To be considered safe the jelly must comply with the standards recommended by the current legislation, the Collegiate Board Resolution No. 12/1978 (Brasil, 1978) and the Collegiate Board Resolution No. 12/2001 (Brasil, 2001), the microbiological standards for pulp established for bacteria of the coliform group, a maximum value of $10^{2} \mathrm{~g}^{-1}$, Salmonella sp absence in $25 \mathrm{~g}$ and for filamentous fungi and yeast a maximum value of $10^{3} \mathrm{~g}^{-1}$. Thus, the processing and the way the product was conditioned suggest that the whole process was carried out within norms established by the legislation and therefore did not compromise food safety. Damiani et al. (2009), Silva et al. (2017) and Santos et al. (2012) found similar results.

Of the 500 untrained panelists in the sensory analysis (100 untrained panelists at each storage time) 65\% were female and 35\% male. The results (Figure 3) show that sensory attributes such as color, flavor, texture and overall impression were significantly $(\mathrm{p}<0.05)$ affected only by the storage time of the jelly, and all these attributes were adjusted to a cubic polynomial model.

The adjusted behavior for the parameters presented in Figure 3 (color, flavor, texture and overall impression) showed a small oscillation over time. Among the above attributes, color presented the lowest mean ( $5.35 \pm 1.79)$, which indicates an acceptance range, in hedonic terms as "indifferent". On the other hand, for the behavior of the sensorial attribute of flavor the averages attributed in the last storage time were lower when compared to the means obtained at the initial time. The average score obtained $(6.19 \pm 1.56)$ classifies it in hedonic terms as "I liked it slightly".

For the sensorial attributes of texture and overall impression, the mean scores obtained in the last storage time $(7.04 \pm 1.47$ and $6.83 \pm 1.36$, respectively) were not lower compared to the means obtained at the initial time. In both cases, the attributes classified in hedonic terms as "I liked moderately".

The taste obtained the highest average of the scores $(7.13 \pm 1.46)$, classifying it on the hedonic scale in "I liked moderately", however, and the lack of knowledge by the majority of the panelists about the sensorial characteristics of this fruit may have been one of the negative points about the purchase intention of the product $(3.54 \pm 1.04)$, which in hedonic terms would classify it as "I do not know if I would buy it".

\section{Conclusion}

The processing of the curriola pulp resulted in a significant decrease in all physical, chemical, nutritional and microbiological variables, except in soluble solids content, titratable acidity, nitrogen-free extract and energy value, which increased after processing.

The storage time factor was a significant influence on the quality of the jelly during twelve months, while no significant difference was found regarding the type of glass packaging factor. However, protein, ash, dietary fiber and sensory attributes of taste and purchase intention, did not change during storage time.

\section{Acknowledgements}

The authors acknowledge the Brazilian sponsors, CAPES - Coordination for the Improvement of Higher Education Personnel (Process No. 88881.068456/2014-01), CNPq - National Council for Scientific and Technological Development (Process No. 304724/2013-0), and FAPEMIG - Foundation for Research Support of the State of Minas Gerais (Process No. PPM -00458-15) for their financial support.

\section{References}

Alves, T. M. A., Silva, A. F., Brandão, M., Grandi, T. S. M., Smâmia, E. F. A., Júnior, A. S., \& Zani, C. L. (2000). Biological screening of brazilian medicinal plants. Memorias do Instituto Oswaldo Cruz, 95(3), 367-373. http://dx.doi.org/10.1590/S0074-02762000000300012. PMid:10800195.

American Public Health Association - APHA. (2001). Compendium of methods for the microbiological examination of food (4th ed.). Washington: APHA.

Andrade, E. C. B. (2006). Análise de alimentos: uma visão química da nutrição. São Paulo: Varela.

Araujo, J. M. A. (2011). Química de Alimentos: teoria e prática (5ª ed.). Viçosa: UFV.

Association of Official Analytical Chemists - AOAC. (2012). Official methods of analysis of the AOAC International (19th ed.). Gaithersburg: AOAC.

Azeredo, H. M. C., Brito, E. S., \& Garruti, D. S. (2012). Alterações químicas durante a estocagem. In H. M. C. Azeredo. Fundamentos de estabilidade de alimentos. Fortaleza: Embrapa Agroindústria Tropical.

Brasil. Ministério da Saúde. Agência Nacional de Vigilância Sanitária - ANVISA. (1978). Resolução - CNNPA nº 12, de 1978. Diário Oficial [da] República Federativa do Brasil.

Brasil. Ministério da Saúde. Agência Nacional de Vigilância Sanitária. (2001). Resolução-RDC no 12, de 02 de Janeiro de 2001. Diário Oficial [da] República Federativa do Brasil. Retrieved from http:// portal.anvisa.gov.br//RDC_12_2001.pdf

Broomes, J., \& Badrie, N. (2010). Effects of low-methoxyl pectin on physicochemical and sensory properties of reduced-calorie Sorrel/ Roselle (Hibiscus sabdariffa L.) jam. The Open Food Science Journal, 4(1), 45-88. http://dx.doi.org/10.2174/1874256401004010048.

Cunha, M. C., Machado, P. S., Araújo, A. B. S., Carvalho, E. E. N., \& Vilas Boas, E. V. B. (2019). Impact of processing and packaging on the quality of murici jelly [Byrsonima crassifolia (L.) Rich] during storage. Nutrition \& Food Science, In press. http://dx.doi.org/10.1108/ NFS-09-2019-0293.

Curi, P. N., Carvalho, C. S., Salgado, D. L., Pio, R., Silva, D. F., Pinheiro, A. C. M., \& Souza, V. R. (2018). Characterization of different native american physalis species and evaluation of their processing potential as jelly in combination with brie-type cheese. Food Science and Technology (Campinas), 38(1), 112-119. http://dx.doi. org/10.1590/1678-457x.01317.

Curi, P. N., Almeida, A. B., Pio, R., Lima, L. C. O., Nunes, C. A., \& Souza, V. R. (2019a). Optimization of native fruit jelly through desirability-based mixture design. Food Science and Technology (Campinas), 39(2), 388-395. http://dx.doi.org/10.1590/fst.31817.

Curi, P. N., Salgado, D. L., Mendonça, K., Pio, R., Ferreira, J. L. G., \& Souza, V. R. (2019b). Influence of microwave processing on the bioactive compounds, antioxidant activity and sensory acceptance of blackberry jelly. Food Science and Technology (Campinas), 39(Suppl. 2), 386-391. http://dx.doi.org/10.1590/fst.18618. 
Damiani, C., Vilas Boas, E. V. B., Soares, M. S. Jr., Caliari, M., Paula, M. L., \& Asquier, E. R. (2009). Avaliação química de geléias de manga formuladas com diferentes níveis de casca em substituição à polpa. Ciência e Agrotecnologia, 33(1), 177-184. http://dx.doi.org/10.1590/ S1413-70542009000100025.

Damiani, C., Silva, F. A., Asquieri, E. R., Lage, E., \& Vilas Boas, E. V. B. (2012a). Antioxidant potential of Psidium guinnensis Sw. jam during storage. Pesquisa Agropecuária Tropical, 42(1), 90-98. http:// dx.doi.org/10.1590/S1983-40632012000100013.

Damiani, C., Asquieri, E. R., Lage, M. E., Oliveira, R. A., Silva, F. A., Pereira, D. E. P., \& Vilas Boas, E. V. B. (2012b). Study of the shelflife of a mixed araça (Psidium guineensis Sw.) and marolo (Annona crassiflora Mart.) jam. Food Science and Technology (Campinas), 32(2), 334-343. http://dx.doi.org/10.1590/S0101-20612012005000050.

Dias, C. S., Borges, S. V., Queiroz, F., \& Pereira, P. A. P. (2011). Influência da temperatura sobre as alterações físicas, físico-químicas e químicas de geleia da casca de banana (Musa spp. ) Cv. Prata durante o armazenamento. Revista do Instituto Adolfo Lutz, 70(1), 28-34.

Ferreira, D. F. (2011). SISVAR: a computer statistical analysis system. Ciência e Agrotecnologia, 35(6), 1039-1042. http://dx.doi.org/10.1590/ S1413-70542011000600001.

Fontes, E. A. Jr., Souza, P. J. C., Nascimento, J. L. M., Santos, S. N., Espíndola, L. S., \& Ferreira, V. M. M. (2009). Antinociceptive and antiinflammatory properties of the ethanolic extract of Pouteria ramiflora roots. Latin American Journal of Pharmacy, 28(6), 812-818.

Franco, B. D. G. M., \& Landgraf, M. (2008). Microbiologia dos alimentos (182 p.). São Paulo, SP: Atheneu.

Freitas, J. B., Cândido, T. L. N., \& Silva, M. R. (2008). Geleia de gabiroba: Avaliação da aceitabilidade e características físicas e químicas. Pesquisa Agropecuária Tropical, 38(2), 87-94.

Jay, J. M. (2005). Microbiologia de alimentos (6. ed). Porto Alegre: Artmed.

Kirca, A., Özkan, M., \& Cemeroğlu, B. (2007). Storage stability of strawberry jam color enhanced with black carrot juice concentrate. Journal of Food Processing and Preservation, 31(5), 531-545. http:// dx.doi.org/10.1111/j.1745-4549.2007.00140.x.

Leong, S. Y., \& Oey, I. (2012). Effects of processing on anthocyanins, carotenoids and vitamin $\mathrm{C}$ in summer fruits and vegetables. Food Chemistry, 133(4), 1577-1587. http://dx.doi.org/10.1016/j. foodchem.2012.02.052.

Machado, W. M., Pereira, A. D., \& Marcon, M. V. (2013). Efeito do processamento e armazenamento em compostos fenólicos presentes em frutas e hortaliças. Ciências Exatas e da Terra, Ciências Agrárias e Engenharia, 19(191), 17-30.

Maia, G. A., Sousa, P. H. M., Santos, G. M., Silva, D. S., Fernandes, A. G., \& Prado, G. M. (2007). Effect of the processing on some components of acerola juice. Food Science and Technology (Campinas), 27(1), 130-134. http://dx.doi.org/10.1590/S0101-20612007000100023.

Miranda, T. G., Lafetá, B. O., Dessimoni-Pinto, N. A. V., \& Vieria, G. (2012). Avaliação do morango em calda submetido a diferentes concentrações de açúcar e condições de armazenamento. Alimentos e Nutrição, 23(2), 307-315.

Morzelle, M. C., Bachiega, P. P., Souza, E. C., Vilas Boas, E. V. B., \& Lamounier, M. L. (2015). Caracterização química e física de frutos de curriola, gabiroba e murici provenientes do Cerrado brasileiro. Revista Brasileira de Fruticultura, 37(1), 96-103. http://dx.doi. org/10.1590/0100-2945-036/14.

Mota, R. V. (2006). Caracterização física e química de geléia de amorapreta. Food Science and Technology (Campinas), 26(3), 539-543. http://dx.doi.org/10.1590/S0101-20612006000300009.

Oliveira, E. N. A., Santos, D. C., Rocha, A. P. T., \& Gomes, J. P. (2014). Desenvolvimento, caracterização e estabilidade de geleia tradicional de umbu-cajá. Revista Brasileira de Fruticultura, 36(3), 640-651. http://dx.doi.org/10.1590/0100-2945-366/13.

Pavlova, V., Karakashova, L., Stamatovska, V., Delchev, N., Necinova, L., Nakov, G., Menkinoska, M., \& Blazevska, T. (2013). Storage impact on the quality of raspberry and peach jams. Journal of Hygienic Engineering and Design, 664, 25-28.

Perfeito, J. P., Santos, M. L., López, K. S. E., Paula, J. E., \& Silveira, D. (2005). Characterization and biological properties of Pouteria torta extracts: a preliminary study. Revista Brasileira de Farmacognosia, 15(3), 183-186. http://dx.doi.org/10.1590/S0102-695X2005000300002.

Queiroz, S. É. E. (2011). Estudos moleculares em Annona crassiflora Mart. Revista de Biologia e Ciência da Terra, 11(2), 23-29.

Rodrigues, P. M., Gomes, J. V. D., Jamal, C. M., Cunha, Á. No., Santos, M. L., Fagg, C. W., Fonseca-Bazzo, Y. M., Magalhães, P. O., Sales, P. M., \& Silveira, D. (2017). Triterpenes from Pouteria ramiflora (Mart.) Radlk. Leaves (Sapotaceae). Food and Chemical Toxicology, 109(Pt 2), 1063-1068. http://dx.doi.org/10.1016/j.fct.2017.05.026. PMid:28533130.

Santos, P. R. G., Cardoso, L. M., Bedetti, S. F., Hamacek, F. R., Moreira, A. V. B., Martino, H. S. D., \& Pinheiro-Sant’Ana, H. M. (2012). Geleia de cagaita (Eugenia dysenterica DC.): desenvolvimento, caracterização microbiológica, sensorial, química e estudo da estabilidade. Revista do Instituto Adolfo Lutz, 71(2), 281-290.

Silva, C. A. M., Simeoni, L. A., \& Silveira, D. (2009). Genus pouteria: chemistry and biological activity. Brazilian Journal of Pharmacognosy, 19(2A), 501-509.

Silva, D. B., Silva, J. A., Junqueira, N. T. V., \& Andrade, L. R. M. (2001). Frutas do cerrado. Brasília: Embrapa Informação Tecnológica.

Silva, E. P., Abreu, W. C., Gonçalves, O. A., Damiani, C., \& Vilas Boas, E. V. B. (2017). Characterization of chemical and mineral composition of marolo (Annona crassiflora Mart) during physiological development. Food Science and Technology (Campinas), 37(1), 13-18. http://dx.doi. org/10.1590/1678-457x.0107.

Silva, E. P., Vilas Boas, E. V. B., \& Xisto, A. L. P. R. (2013). Characterization and development of marolo (Annona crassifolia Mart.). Food Science and Technology (Campinas), 33(4), 666-675. http://dx.doi. org/10.1590/S0101-20612013000400011.

Silva, M. C. Jr. (2009). Mais de cem árvores do Cerrado: guia de campo. Brasília, DF: Editora Rede de Sementes do Cerrado.

Silva, P. T., Lopes, M. L. M., \& Valente-Mesquita, V. L. (2006). Efeito de diferentes processamentos sobre o teor de ácido ascórbico em suco de laranja utilizado na elaboração de bolo, pudim e geléia. Food Science and Technology (Campinas), 26(3), 678-682. http://dx.doi. org/10.1590/S0101-20612006000300030.

Souza, V. R., Pereira, P. A. P., Queiroz, F., Borges, S. V., \& Carneiro, J. D. S. (2012). Determination of bioactive compounds, antioxidant activity and chemical composition of Cerrado Brazilian fruits. Food Chemistry, 134(1), 381-386. http://dx.doi.org/10.1016/j. foodchem.2012.02.191.

Stone, H., Bleibaum, R., \& Thomas, H. A. (2012). Sensory evaluation practices. New York: Academic Press.

Streit, N. M., Canterle, L. P., Canto, M. W., \& Hecktheuer, L. H. H. (2005). As clorofilas. Ciência Rural, 35(3), 748-755. http://dx.doi. org/10.1590/S0103-84782005000300043.

Zou, M. L., Moughan, P. J., Awati, A., \& Livesey, G. (2007). Accuracy of the Atwater factors and related food energy conversion factors with low-fat, high-fiber diets when energy intake is reduced spontaneously. The American Journal of Clinical Nutrition, 86(6), 1649-1656. http:// dx.doi.org/10.1093/ajen/86.5.1649. PMid:18065582. 